\title{
Dictionaries of Canadian English
}

John Considine, Department of English, University of Alberta, Edmonton, Canada (jc18@ualberta.ca)

\begin{abstract}
The lexicographical record of English in Canada began with wordlists of the late eighteenth, nineteenth, and early twentieth centuries. From the beginning of the twentieth century onwards, the general vocabulary of English in Canada has been represented in bilingual and monolingual dictionaries, often adapted from American or British dictionaries. In the 1950s, several important projects were initiated, resulting in the publication of general dictionaries of English in Canada, and of dictionaries of Canadianisms and of the vocabulary of particular regions of Canada. This article gives an overview of these dictionaries and of their reception, contextualizing them in the larger picture of the lexicography of Canada's other official language, French, and of a number of its non-official languages. It concludes by looking at the future of English-language lexicography in Canada, and by observing that although it has, at its best, reached a high degree of sophistication, there are still major opportunities waiting to be taken.
\end{abstract}

Keywords: DICTIONARY, LEXICOGRAPHY, CANADIAN ENGLISH, CANADIANISMS, NATIONAL DICTIONARIES, CANADIAN FRENCH, CANADIAN FIRST NATIONS LANGUAGES, BILINGUAL DICTIONARIES, REGIONAL DICTIONARIES, UNFINISHED DICTIONARY PROJECTS

Opsomming: Woordeboeke van Kanadese Engels. Die leksikografiese optekening van Engels in Kanada begin met woordelyste van die laat agtiende, neëntiende en vroeë twintigste eeue. Van die begin van die twintigste eeu af en verder, is die algemene woordeskat van Engels weergegee in tweetalige en eentalige woordeboeke, dikwels met wysiginge ontleen aan Amerikaanse en Britse woordeboeke. In die 1950's is verskeie belangrike projekte onderneem wat gelei het tot die publikasie van algemene woordeboeke van Engels in Kanada, en van woordeboeke van Kanadeïsmes en van die woordeskat van bepaalde streke van Kanada. Hierdie artikel gee 'n oorsig van dié woordeboeke, en van hul ontvangs, deur hulle in die konteks te plaas van die groter patroon van die leksikografie van Kanada se ander offisiële taal, Frans, en van 'n aantal van sy nieamptelike tale. Dit eindig deur na die toekoms van Engelstalige leksikografie in Kanada te kyk, en deur op te merk dat, alhoewel dit, op sy beste, 'n hoë graad van sofistikasie bereik het, daar nog belangrike geleenthede wag om te benut.

Sleutelwoorde: WOORDEBOEK, LEKSIKOGRAFIE, KANADESE ENGELS, KANADEISMES, NASIONALE WOORDEBOEKE, KANADESE FRANS, KANADESE EERSTENASIETALE, TWEETALIGE WOORDEBOEKE, STREEKSWOORDEBOEKE, ONVOLTOOIDE WOORDEBOEKPROJEKTE

\section{The beginnings of English-language lexicography in Canada}

The history of lexicography in Canada goes back more than four and a half cen- 
turies, to a list of fifty-four Iroquoian lexical items noted down by Jacques Cartier in 1534 (Cartier 1534/1986: 224-226). More substantial lexicographical work was undertaken in the seventeenth century, when French-speaking missionaries gathered wordlists of the languages of some of the First Nations they encountered; these include vocabularies of Montagnais, Old Algonquin, Ottawa, Eastern Abenaki, Huron, and Onondaga (Goddard 1996). From 1743 onwards, another French-speaking missionary, Pierre-Philippe Potier SJ, made informal notes on the distinctive French usages he encountered in Quebec City and on his travels further west, amounting to just over two thousand lexical items (Halford 1994). These made the first approach to French-Canadian lexicography.

By the end of the eighteenth century, Anglophones in Canada were also making wordlists: in 1792, for instance, Captain G.C. Pulling made a list of 111 items of the now-extinct Beothuk language, obtained from a native speaker called Oubee, a young girl who had been kidnapped by English-speaking Newfoundlanders the year before and would die in captivity in England (Hewson 1978: 11-32). Almost exactly contemporary with this wordlist was one obtained in less criminal circumstances, the glossary of 134 items printed in George Cartwright's Journal of Transactions and Events During a Residence of Nearly Sixteen Years on the Coast of Labrador in 1792 (Cartwright 1792: 1. ix-xvi). This marks the beginning of the study of the distinctive English vocabulary of Canada.

For more than a hundred years after Cartwright's glossary, this study remained at a very primitive stage. While the English of the independent United States was coming to be recognized by lexicographers in that country as having its own rules and its own integrity, the English of the Dominion of Canada was seen as aberrant. The lexical item Canadian English first occurs as the title of a lecture given in Toronto by the Revd. A.C. Geikie in 1857. Geikie was an immigrant from Scotland and the minister of a Presbyterian church in Berlin (now Kitchener), in the traditionally Anglophone province of Ontario, and the strongly prescriptive and conservative tone of his lecture may betray the linguistic anxiety of someone triply remote from the norms of the metropolitan elite: as a Scot, as a resident of Canada, and as a resident of a town with a very substantial German-speaking population (see Bassler 1991: 110-14). In Canada, he remarked, the English language was in a bad way (Geikie 1857/1980-: 345):

It can be shown that words, unrecognized by good authors, are daily used; that words duly recognized are used in improper ways; ... that extraordinary creations, and combinations of letters and phrases, are extensively circulated without supplying a recognized want, or contributing in any sense to the enrichment of the language.

This attitude to Canadian English was not idiosyncratic at the time (Chambers 1993). While it was current, it is not surprising that there should have been no dictionaries of the newly-recognized language variety. Wordlists of Canadian 
French in the nineteenth century were often compilations of so-called "locutions vicieuses" or "barbarismes" (e.g. Dulong 1966: entries 12, 23, 40, 46 etc.), but Canadians did not think their English was important enough even to give this sort of negative attention to it. Wordlists appeared sporadically, but on a very modest scale. So, for instance, Julian Moreton's Life and Work in Newfoundland (Moreton 1863: 28-51), has a glossary of 89 lexical items, and other Newfoundland collections are noted by Story (1975a). An early mainland glossary, of 32 lexical items, was included in a pamphlet of church news printed in New Brunswick in 1889 ("Brief Glossary" 1889/1980-), but can never have been widely read, and is now so rare as to have been excluded from the standard bibliography of writings on Canadian English because no copy could be found (see Avis and Kinloch 1978: entry 706). The most thorough documentation of nineteenth-century Canadian vocabulary was done abroad, in dictionaries of Americanisms and in what became the Oxford English Dictionary, which are outside the scope of this survey.

This situation began to change in the early twentieth century. In 1905, a dictionary published in Canada acknowledged at last that Canadian English shared some features with the English of the United States rather than with that of Great Britain. This was Nugent's Up-To-Date English-French and FrenchEnglish Dictionary (1905), revised by the translator and miscellaneous writer Sylva Clapin from an earlier Montréal publication. It included so-called Americanisms as headwords in the English-French section (such as sidewalk rather than British English pavement) and among the glosses in the French-English section. Before his revision of Nugent's Dictionary, Clapin had already produced a Dictionnaire canadien-français (1894), which treated the French of Canada without the prejudices of the previous century, and A New Dictionary of Americanisms: Being a Glossary of Words Supposed to be Peculiar to the United States and the Dominion of Canada (1902), in which a number of words were identified specifically as Canadian. Clapin was a native of Quebec, and he had lived in the United States: for him, the French of Quebec was a beloved heritage rather than a poor relation of Parisian French; English was an alternative to French rather than a language of unquestionable and overpowering prestige; and British English was an alternative to American English rather than the preferable variety of the language. He was not simply a libertarian in matters of usage another of his works was an "inventaire de nos fautes les plus usuelles" in the writing of French (Clapin 1913). However, his openness to North American, and especially to Canadian, linguistic difference may be contrasted with Geikie's defensiveness.

The first Canadian dictionary to include Canadian English was, then, a product of Quebec; the first separately-published wordlist of Canadian English was a product of the Canadian West, an area which was largely Anglophone, but which was, like Quebec, more resistant to British linguistic norms than the conservative Anglophone heartland of Ontario. This was the Western Canadian Dictionary and Phrase-Book of John Sandilands, published in Winnipeg in edi- 
tions of 1912 and 1913, with 853 and c. 1530 entries respectively. The Western Canadian Dictionary was originally produced with new immigrants from England in mind, and the title-page of the first edition boasted "a careful selection of items of general information immediately helpful to the newcomer". Some of the entries in the first edition, such as irrigation, do indeed provide encyclopedic information, while others identify lexical items likely to be unfamiliar to a speaker of British English, such as snow-shoes or the verb trek, whose borrowing from South African English Sandilands must have supposed to be distinctively Canadian, although the word was in fact beginning to be used across the British Empire: OED (s.v. trek v., sense 1a(b)) has an Australian citation of 1911 and an English one of 1912. Other entries celebrate Western Canadian cities, institutions, or scenery, e.g. the entry Foothills, which begins "The natural features of Alberta combine the beauties of prairie and mountain scenery", and continues in the same vein. The second edition was more evidently meant to be read for pleasure: a note at the end recommends "mailing copies to friends in the OldCountry who want to know about Canada", and one issue was sold as the "Stampede Edition", presumably for sale as a souvenir at the Winnipeg Stampede of 1913 (there is a copy in the National Library of Canada). It has more of a jokey quality than the first: for instance, s.v. Firefly, after a simple definition, Sandilands tells the story of the two Irishmen who, "tired after a day's travel on foot, sought refuge from the mosquitoes under a haystack. In the darkness Pat espied a fire-fly, and declared to Mike that the mosquitoes were after him again, with lanterns". But Sandilands was not just a humorist; he had a good ear for vocabulary, and the Western Canadian Dictionary provides the Oxford English Dictionary with its first examples of movie "film" (singular, as opposed to the movies); B.S. as an abbreviation for bullshit with the sense "nonsense"; make the grade "be successful"; kale "money", and other lexical items. It was not such a substantial work as Charles Pettman's coverage of South African English in Africanderisms, with which it was almost exactly contemporaneous; nor is it to be compared with E.E. Morris's ambitious historical dictionary of Australian usage, Austral English, or with the fine account of Anglo-Indian usage in Henry Yule and A.C. Burnell's Hobson-Jobson. In the first years of the twentieth century, English-language lexicography was, in other words, practiced with less sophistication in Canada than in several of the other major dominions.

\section{The first major Canadian dictionaries of English}

After the publication of Sandilands's Western Canadian Dictionary, there was a long hiatus in English-language lexicography in Canada. This stagnation contrasted with the flourishing state of French-Canadian lexicography: the Société du parler français au Canada, founded in 1902, produced a 700-page dictionary of Franco-Canadianisms, Glossaire du parler français au Canada, in 1930, and one of its members, Louis-Alexandre Bélisle, drew on this to make a general dictionary of all the French used in Quebec, whether distinctively Canadian or 
common to Canada and France, in the 1950s. This was being sold in fascicles in Quebec supermarkets at a time when interest in Canadian English was still at a decidedly primitive stage. A characteristic attitude is that expressed by a representative of the Canadian Broadcasting Company (CBC) in 1949. A member of an Ontario school board had attacked the English spoken by CBC announcers, complaining for instance that they stressed the first syllable of research rather than the second (this is in fact standard North American usage). The reply was that in fact the announcers read their scripts in advance, consulting a dictionary for help with the pronunciation of difficult words - and that "[w]e have an Oxford and a Webster's dictionary" (Toronto Daily Star 13 January 1949: 29). The implication was clearly that although Canadian English was neither identical with British nor with American English, it could be regarded by dictionaryusers as a mixture of the two.

This principle underlay the making of the first general dictionary aimed at the Canadian market, the 32 000-word Winston Simplified Dictionary for Canada, published in 1937. This belonged to a large family of non-scholarly American dictionaries. The first of these, which appeared in 1919 as The Winston Simplified Dictionary, claimed ease of use as its selling point: "You never have to look up the meaning of the meaning" (quoted Tebbel 1972-81: 3. 222). It was revised in 1936 as the New Winston Simplified Dictionary for Young People, and then repackaged, adapted, or further revised in a long line of dictionaries for children or for schools, and of college editions, advanced editions (these two might be identical), and encyclopedic editions (Tebbel 1972-81: 3. 614; Kister 1977: 166, 325-26). The Canadian edition, prepared by the language historian and dialectologist Henry Alexander of Queen's University, substituted British usages for some of the American usages in the original dictionary, and likewise substituted lists of Canadian premiers and governors-general for the list of American presidents in the original. It was reviewed thoughtfully if a little coolly in the Toronto Globe and Mail, which began with an interesting description of Canadian usage as "split between English custom in universities and American in business and newspapers, with most Canadians making their own compromises in no orderly fashion". The review (Globe and Mail 11 September 1937: 8) ended by observing:

Of course it is not true, as the editors assume, that Canadians invariably follow English practice any more than it would be true that we invariably follow American standards. That the problem of a new Canadian dictionary is more subtle and difficult than Dr Alexander supposes will not interfere in the least with the rightful popularity of the new Winston dictionary in Canada. This is the first publisher to be so enterprising as to try to suit our peculiar needs.

By the time of the last reissue of a revised edition of this dictionary in 1974 as The Winston Canadian Dictionary for School, Home, and Office, the word count had crept up to 38550 , and the publishers claimed to have sold almost two million copies (Winston Canadian Dictionary 1974: iv, back cover). The next generation 
of Winston Canadian dictionaries, to be discussed below, had by this time overtaken this work, which was fundamentally an undistinguished piece of lexicography but, as the Globe and Mail said, an enterprising publication.

Despite the existence of the Winston dictionary, some Canadians were still, at the end of the 1950s, prepared to dismiss Canadian lexicography as pointless. When the idea of a Canadian dictionary was introduced to the Dean of Arts and Science at Dalhousie University in Nova Scotia, for instance, he remarked that he "had always found British definitions satisfactory". On being told that one British dictionary defined hockey as "a game played with a ball and stick" (hockey in Canadian English means ice hockey, a game of great cultural importance, played with a hard disc called a puck, as opposed to field hockey, the game usually called hockey in British and South African English), he replied that no Canadian would need to look that word up anyway (Halifax Chronicle-Herald 24 April 1959: 28). By that time, however, new projects, much more interesting than Winston's, were under way. In 1954, the founding meeting of the Canadian Linguistic Association was held at the University of Manitoba, in Winnipeg. At this meeting, "some discussion was given to the possibility of preparing dictionaries of Canadian English" (Scargill 1967: vi). The desirability of preparing a bilingual English-French dictionary, which would replace Clapin's long-obsolete work, was also raised. One of the first articles in the association's journal, published in 1955, was called "Lexicographic Challenges of Canadian English", and concluded with the hope that it might help "to give impetus to plans for an eventual Dictionary of Canadian English, based upon historical principles" (Lovell 1955a: 5). It was the work of Charles Lovell, a former member of the staff of the Dictionary of Americanisms, who went on to contribute a two-part article on the principles of collecting for the dictionary in 1956 (Lovell 1955b, 1956). In the following year, the association formed a Lexicographical Committee and began to plan three types of English-language dictionaries: a series for use by schoolchildren and undergraduates; a dictionary of Canadianisms; and a larger historical dictionary of the English language in Canada (Scargill 1967: vi). Separate committees were subsequently established with French-Canadian lexicography and Ukrainian lexicography as their concerns; a founding member of the Canadian Linguistic Association, J.B. Rudnyckj, produced a Ukrainian etymological dictionary in fascicles from 1962 onwards.

In 1958, the Toronto publishing house of W.J. Gage agreed to publish a dictionary of Canadianisms, to be edited by Lovell (Scargill 1967). At his death in 1960, Lovell left this project well begun, but far from completion. What followed was an exemplary collaboration between commercial, academic, and governmental sponsors of a dictionary project. Gage purchased Lovell's lexicographical collection from his estate and invited two members of the Canadian Linguistic Association, Matthew Scargill and Walter Avis, to take over the editing of the unfinished dictionary. The University of Alberta at Calgary (now the University of Calgary) provided space and secretarial assistance for a lexi- 
cographical centre which gave the dictionary a home from 1960 to 1964, and the University of Victoria did so after 1964. Walter Avis was given study leaves for dictionary editing purposes by the Canada Council and the university at which he taught, the Royal Military College of Canada. A number of academics made materials for the dictionary available to its editors. Gaston Dulong, secretary of the Société du parler français au Canada, acted as consultant for French-Canadian etymologies. The whole undertaking was remarkable for its collegiality and efficiency. The Dictionary of Canadianisms $(D C)$ was completed in 1967, the centenary of the confederated Dominion of Canada.

The dictionary itself was edited on historical principles, with a wordlist confined to lexical items or senses of lexical items "native to Canada or ... distinctively characteristic of Canadian usage though not necessarily exclusive to Canada" (DC 1967: xiii). Sandilands and Clapin, by contrast, had simply noted forms which they had encountered in Canada and knew or supposed to be different from British usage, and many of these were American rather than Canadian. The bibliography included around two thousand books and pamphlets and around five hundred journals, and although this list was far from comprehensive, it was most impressive. No attempt was made to document spoken English, which would have made the lexicographic process very much longer and more expensive. The ten thousand entries were handsomely laid out, with a sprinkling of useful line drawings. The publishers' foreword described the dictionary as "a contribution to Centennial thinking" and hoped that it would contribute not only to the study of language but also to the understanding of Canadian identity (Wees 1967). The American lexicographer Sidney Landau perceived the same double function when he called the dictionary "an indispensable source from a linguistic point of view and a fascinating treasury of cultural information about Canada's past" (Landau 1984/1989: 340). An abridgement was published six years later as A Concise Dictionary of Canadianisms. DC had been planned as a pilot volume for a major Dictionary of Canadian English on Historical Principles, which would presumably have been on the same sort of scale as the Dictionary of Americanisms on which Lovell had worked (Scargill 1958: 117). Collecting for this project was apparently still in progress at the Lexicographical Research Centre in Victoria in the late 1970s (McConnell 1978: 127 note). The dictionary was, however, never published, and the files of the Lexicographical Research Centre, now in the University of Victoria Archives, appear to have been closed in 1983 (British Columbia Archival Union List 2003).

The Dictionary of Canadianisms was not Gage's only contribution to Canadian lexicography in the 1960s. The series of general dictionaries which had been planned by the lexicographical committee of the Canadian Linguistic Association was already far enough in planning to be discussed in print in 1958 (Scargill 1958: 116f). By this stage, permission had been obtained to base the proposed dictionaries on the graded series of American school dictionaries published by Thorndike-Barnhart, and this made it possible to complete them 
expeditiously. They were the work of good scholars - Avis, Scargill, Lovell, and R.J. Gregg of the University of British Columbia - and were rather more thoughtfully developed from their American bases than the Canadian edition of the Winston dictionary had been. The series began with The Beginning Dictionary, with about 20000 entries, which was published in 1962; The Intermediate Dictionary, with 64000 entries, followed in 1963; and The Advanced Dictionary, with 90 000, in 1967 (overview in Avis and Kinloch 1978: entries 151-53). Revisions of these dictionaries will be mentioned below.

Two other dictionary projects dealing with Canadian English had been launched by 1960. The first of these takes us back to the highly distinctive English of Newfoundland, which had, as we have seen, been an object of attention since the very beginnings of interest in Canadian English. In 1956, George Story, a professor at Memorial University (the principal university of Newfoundland) with a background in English literature of the early seventeenth century, published a fourteen-page pamphlet called A Newfoundland Dialect Dictionary: A Survey of the Problems. In the following year, he reported to the Canadian Linguistic Association on his work compiling such a dictionary. Story stated in his report: "I have on cards what I believe to be most of the words in general use in the Island ... [and] a fairly good, though not complete, record of words peculiar to [certain named locations]" (Story 1957: 51-52). He also acknowledged that "the limits of individual collecting are being reached", and that, since the project would almost certainly not be completed for many years, he would publish a preliminary glossary "in about three years" (Story 1957: 53). This preliminary glossary appears not to have materialized, but the collaboration which Story looked for did take place; he was joined by two colleagues at Memorial, William Kirwin and John Widdowson. Their work, whose results will be discussed in the next section, was coordinated with other parts of a wider project concerned with the preservation of Newfoundland heritage. This had been initiated by the head of the department of English at Memorial, Edgar Seary, formerly of Rhodes University, Grahamstown (for him, see Story 1975b). In this project, "the languages (especially the English language), the place- and family-names, and the folklore of Newfoundland were to be subjected to a scrutiny worthy of their importance for Newfoundlanders and their interest to others" (DNE 19821: v; cf. Seary 1971 and Seary 1977). This concern to set lexicographical research in a wider cultural context was exemplary, and continues in the work of the English Language Research Centre at Memorial (Memorial University 2003).

The second important project of the late 1950s and early 1960s was the $\mathrm{Ca}$ nadian Dictionary/Dictionnaire canadien, prepared at the Lexicographic Research Centre/Centre de Recherches lexicographiques at the Université de Montréal. Its chief editor was Jean-Paul Vinay, a translator and educator who had been born in Paris, founded the linguistics department at Montréal, and would go on to be Matthew Scargill's successor as Chair of the Linguistics Department at the University of Victoria. He was assisted by the distinguished translator 
Pierre Daviault, and (until 1957) by Henry Alexander, who had adapted the Winston dictionary for Canadian use a quarter of a century earlier. The Canadian Dictionary was a practical, synchronic dictionary for translators rather than a dictionary of record. It was, on its publication, described as a "concise edition"; it only contained about 11000 English headwords (Avis and Kinloch 1978: item 621). A multi-volume successor was anticipated with interest, and one reviewer even urged readers to note "minor blemishes" and communicate them to the editors: "all such information will feed into the archives for the larger volumes of the dictionary to which we now look forward" (Gregg 1962: 71). These volumes never appeared, although a more substantial Bilingual Canadian Dictionary/Dictionnaire canadien bilingue is now in preparation (University of Ottawa 2003). The French text of the Canadian Dictionary falls outside the scope of this article, but it is significant that the English it treated was meant to be specifically Canadian English. Two of the editors wrote à propos of the dictionary that "il est temps que nos variétés d'anglais et de français sortent de leur lieu d'incubation, et accèdent à la dignité de particularismes reconnus" (Vinay and Daviault 1958: 110). Here, as in the lexicography of Sylva Clapin, Francophone Canadians can be seen treating the English of Canada with more respect than their Anglophone neighbours.

Finally, two more Canadian editions of American dictionaries appeared in the 1960s. The first was the substantial Funk and Wagnalls Standard College Dictionary: Canadian Edition. This was a revision for Canadian readers of a $150000-$ entry American dictionary (for which see Landau 1984/1989: 341-42); it had, as did the American original, an essay on Canadian English by Walter Avis. The second was a new Winston Dictionary of Canadian English, Intermediate Edition (1969), based on the Holt Intermediate Dictionary of American English of 1966: the publishing companies of John Winston and Henry Holt had merged in 1960 (Dzwonkoski 1986). The new dictionary, of about 65000 entries, was reprinted in paperback as The Compact Dictionary of Canadian English, and abridged as The Winston Dictionary of Canadian English: Elementary Edition, with about 30000 entries (Avis and Kinloch 1978: entries 490, 492-93). It was made under the editorship of Thomas M. Paikeday, who had been born in India and had lectured at the University of Delhi before beginning his lexicographical career working for Gage. Thereafter, Paikeday turned his attention to what would become the New York Times Everyday Dictionary (1982); a subsequent Canadian dictionary of his will be discussed below.

\section{Regional and general dictionaries in the 1970 s and $1980 \mathrm{~s}$}

The next two decades of English-language lexicography in Canada saw three kinds of activity: the proliferation of general dictionaries, none of them wholly original; the making of two major regional dictionaries; and the making of a number of humorous, local, and technical wordlists of minor importance.

The first area of activity can be summed up briefly. In 1973, a new Cana- 
dian edition of Funk and Wagnalls Standard College Dictionary was published, this time based on the revised American edition of 1968 (for which see Landau 1984/1989: 341-42). It was followed in 1980 by The Houghton Mifflin Canadian Dictionary of the English Language. The title of this book concealed its American origins; it was in fact a Canadian edition of the American Heritage Dictionary of the English Language, which made the good features of that dictionary, for instance its ample illustrations and learned appendix of Indo-European roots, available to Canadian readers as well as its bad features, for instance its conservative and authoritarian ideology. It has been widely used in Canadian universities and in public life, being quoted in at least one Canadian legislature, and drawn on in the rulings of Canadian federal agencies (Hansard [Nova Scotia] 2001; Canadian International Trade Tribunal 1989; Federal Court Reports 1994). Finally, in the 1970s and 1980s, the Gage dictionary series underwent revisions and changes of title: The Beginning Dictionary became the Canadian Junior Dictionary in 1977 and the Gage Junior Dictionary in 1985; The Intermediate Dictionary became the Canadian Intermediate Dictionary in 1979; The Senior Dictionary became the Gage Canadian Dictionary in two editions of 1973, then the Canadian Senior Dictionary in its fourth edition, of 1979, then The Gage Canadian Dictionary again in its fifth, of 1983.

The second area of activity in the period, the making of regional dictionaries, is much more interesting and important. George Story had known in the 1950s that the dictionary of Newfoundland English which he had begun would take many years to finish. It was actually in progress for about a quarter of a century, supported by Memorial University and the Canada Council: here, as in the making of the Dictionary of Canadianisms, government money and support from a university came together fruitfully. Articles on the making of the dictionary were published by Story, Kirwin, and Widdowson in 1973, by Story and Kirwin in 1974, and by Kirwin (illustrated with sample entries) in 1975. In 1977 specimens of the dictionary were circulated in draft form. The completed Dictionary of Newfoundland English (DNE) was published in 1982, followed by a second edition with an extensive supplement in 1990; Memorial University made its entire text available online in 1999.

The completed dictionary ran to about 4500 entries; the second edition, with 1500 new or expanded entries, has an entry count of 5224 (DNE 1999: search screen). The selection criteria were that words which appear to have originated in Newfoundland or to have been first recorded in books about Newfoundland should be included, as should "words which are characteristically Newfoundland by having continued in use here after they died out or declined elsewhere, or by having acquired a different form or developed a different meaning, or by having a distinctly higher or more general degree of use" (DNE 1982: xii). These criteria called for some careful judgements, one of which (the case of high-liner) has subsequently been written up in some detail by Kirwin and Story (1986). DNE was constructed on historical principles, with extensive cross-referencing to other dictionaries. The bibliography of the printed and 
manuscript sources in the first edition ran to over five hundred items, excluding periodicals. To this written material, which made up $42 \%$ of the dictionary's sources, was added data from the extensive collections of the Memorial University of Newfoundland Folklore and Language Archive (including 2000 tape-recordings), and other field records (DNE 1982: xxi-xxvi). The DNE was originally expected to be largely of local interest: the publisher sent three thousand copies of the first printing to Newfoundland, and fewer than five hundred to bookstores in the rest of Canada (Globe and Mail 13 November 1982: 8). However, it was reviewed with great warmth across Canada. For instance, one of the leading authorities on Canadian English, J.K. Chambers of the University of Toronto, praised it in a national paper as "more than a book of definitions ... a flahoolach repository of the folklore and the folkways and even the sound and the spirit of ... Newfoundland" flahoolach is a Newfoundland word meaning "lavish, generous") and added that it "is a book which, combined with a working fireplace, can use up your whole winter" (Globe and Mail 22 December 1982: 19).

In 1979, work began on a dictionary of the English of Prince Edward Island, which, like Newfoundland, is a large island lying off the east coast of Canada, with a long history of settlement by Anglophones. This was undertaken by Terry Pratt, a professor of English at the University of Prince Edward Island. Like the Dictionary of Canadianisms and DNE, and indeed earlier Canadian dictionaries such as Clapin's Dictionnaire canadien-français, this dictionary project had a clear sense of language as heritage. Early in the project, Pratt observed that "[j]ust about everybody is interested in language when it comes right down to it", and that his dictionary appealed to this interest and also to "Island pride and the swelling interest in heritage matters" (Montreal Gazette 23 September 1980: 21; see also Considine 2000: 325). Although the resulting Dictionary of Prince Edward Island English (DPEIE) was not part of a cultural research project as elaborate as that into which DNE fitted, it shared the larger dictionary's concern with the contextualization of lexicography in other kinds of verbal culture. So, for instance, it concluded with the remark that a dictionary of Prince Edward Island sayings would be desirable (DPEIE 1988: 179); in fact, Pratt subsequently produced such a volume, in collaboration with Scott Burke, who had been his editorial assistant on DPEIE.

DPEIE was published in 1988. Like DNE, it used historical evidence gathered in a reading programme as well as material gathered directly from informants, the latter being proportionally more important than in DNE. This made it possible for Pratt to specify regional and social variation in impressive detail: so, for instance, alder mud "mud from alder swamps used as fertilizer" is labelled "Archaic. Occasional in Egmont, infrequent elsewhere but rare in Charlottetown; significantly older, male; especially less educated". This sociolinguistic depth was made possible in part by stringent selection criteria, which excluded, among other classes of vocabulary, most proper nouns, most slang, and most general Canadianisms (DPEIE 1988: xii-xiii), bringing the word count 
right down to 873 main entries (DPEIE 1988: xxii). G.M. Story suggested in a review that "the rather small lexical corpus which the work contains" might have been "restricted by the nature of the collecting instruments and the special interests of the investigators" (Story 1989: 392). Responding to a draft of an article which made a similar point, Pratt argued that a much larger word count would simply have meant unnecessary overlap with other dictionaries (1999; cf. Considine 2000: 325-27). To that, it might be replied at least that the excellence of his dictionary inevitably leads to the wish that it had been larger.

Smaller and much less thorough or scholarly local wordlists were also produced in the period. For instance, Lewis J. Poteet's The South Shore Phrase Book documents about six hundred lexical items collected by the author in parts of Nova Scotia, including the old and linguistically interesting German settlement of Lunenburg, and Tom Parkin's WetCoast Words collects about seven hundred lexical items from British Columbia (the title alludes humorously to the high rainfall characteristic of the Pacific coast of Canada). These publications are of some interest, not least as sketches of what might be done in the study of the regional vocabulary of Canadian English, but their technical level is that of Sandilands's dictionary. A slightly different kind of wordlist, Mark Orkin's successful Canajan, Eh? of 1973, relied for its effect on the re-spelling of lemmata and defining text to approximate informal Canadian speech. This had already been done for Australia in Let Stalk Strine (Lauder 1965), for Texas in the Illustrated Texas Dictionary of the English Language (Everhart 1968), and for South Africa in Ah Big Yaws? (Malong 1972); examples from these and other dictionaries are most readily available in the work of David Crystal (1995: 410, 357; 1998: 23). In the 1980s, specialized dictionaries aimed exclusively at the Canadian market - a Canadian Dictionary of Safety Terms, a Canadian Dictionary of Abbreviations, and so on - also began to appear. Although these are outside the scope of this survey, they are worth mentioning because they suggest an increasing sense of the distinctiveness of Canadian usage.

\section{The new generation of Canadian dictionaries of English: the 1990s}

Something new happened in Canadian lexicography in 1990, when Thomas Paikeday completed his Penguin Canadian Dictionary, a general dictionary of about 75000 entries. This was the fruit of a long-standing interest in the possibilities of computational methods in lexicography. Paikeday assembled a 20000 000-word corpus, largely from Canadian sources, with a particular reliance on machine-readable text of the Globe and Mail, and used this to establish a wordlist. He also used it to ascertain regular collocations, a subject of great interest to him (see e.g. Paikeday 1989, 1992), and provided over 40000 collocational and idiomatic examples of uses of the words he defined. The result was the first general dictionary wholly made in Canada. It was not entirely successful. "In too many places," one incisive review pointed out, "one short definition ... has to serve as the anchor for a whole slew of context phrases and sen- 
tences showing clearly different meanings, with not enough information about those differences to serve the user properly"; moreover, the reviewer continued, the wordlist of the dictionary was sometimes haphazardly chosen, homographs were not differentiated, and statements about Canadian usage were sometimes questionable (Globe and Mail 18 August 1990: C16). All of these criticisms could no doubt be referred to Paikeday's reliance on a corpus which was too small and crudely selected to do all that he needed.

The decade which began with the Penguin Canadian Dictionary was marked by the vigorous, and sometimes bewildering, development of Canadian dictionaries. Gage developed a particularly elaborate range. The flagship, the Gage Canadian Dictionary, was revised in 1996 and again in 2000, and was released in electronic form in 1996. By 2002, it was accompanied by a concise edition (1 024 pages, 95000 entries), and by no fewer than five graded dictionaries for younger readers, who could start with the Gage Canadian First Book of Words (64 pages, 600 one-word entries), move up to the Gage Canadian Beginner's Dictionary (128 pages, 1200 entries) when they started reading properly, then turn to the Gage Canadian School Dictionary (384 pages) at the age of eight or nine, before graduating to the 800-page Gage Canadian Junior Dictionary a year or two later, and then to the 1414-page Gage Canadian Intermediate Dictionary, which might be expected to see them through to the age of sixteen (details from Gage Learning and National Library of Canada). Trained scholars worked on these dictionaries: the principal editor of the 1996 Gage Canadian Dictionary had written and published a doctoral thesis on social and regional variation in Canadian English (De Wolf 1992), and its general consulting editor was Terry Pratt.

A rival to the Gage Canadian Dictionary appeared in 1997 as the ITP Nelson Canadian Dictionary of the English Language. This dictionary, almost exactly the same length as Gage at 1728 pages, with an entry count of about 150 000, was an adaptation of the third edition of the American Heritage High School Dictionary, itself an abridgement of the American Heritage Dictionary which had been adapted nearly two decades earlier as the Houghton Mifflin Canadian Dictionary. Its treatment of Canadian English was carefully done, and it was adorned with what its editors zealously called "a toboggan-load of useful information" about Canadian geography and institutions (ITP Nelson Canadian Dictionary 1997: vii). It was well received, one reviewer going so far as to call it "a brave, elegant, erudite and eloquent gift to this much beleaguered nation" (Globe and Mail 21 December 1996: D14).

A rival to the Gage Canadian Dictionary and ITP Nelson Canadian Dictionary was published in 1998: the Canadian Oxford Dictionary (COD), very much their length at 1728 pages and about 130000 entries (COD 1998: dustcover). Its chief editor, Katherine Barber, had worked on the Bilingual Canadian Dictionary/Dictionnaire canadien bilingue project at the University of Ottawa before being recruited by Oxford University Press: a reminder of the importance of Canadian bilingualism in English-Canadian lexicography and, like Terry Pratt's work for Gage, a reminder of the contributions of universities to the making of trade 
dictionaries. $C O D$ was, perhaps surprisingly, the first major entry of Oxford University Press into the Canadian dictionary market, although it had been rumoured in the 1960s that the press was preparing "a Canadian English dictionary" (Gregg 1962: 68). It was based on a two-million-word citation database of Canadian quotations selected in the course of a substantial reading programme which drew on 20000000 words of Canadian text; it also drew on the Oxford English Dictionary's 20000 000-word citation database of largely nonCanadian quotations. These databases were used with greater sophistication than that on which Paikeday founded the Penguin Canadian Dictionary. One reason for this is that the $C O D$ reading programme took in a much wider range of material than Paikeday could hope to do; and a reason for that is that $C O D$ was produced by a full-time staff of five, with the assistance of a number of outside contributors, including several members of the main Dictionary Department of Oxford University Press in Oxford. It is no longer possible for any general dictionary of English to be produced by a single person.

Its publishers claimed as the dictionary was launched that $C O D$ "establishes a new authoritative standard for dictionaries in Canada" and "serves Canadians like no other dictionary" (Oxford University Press 1997), even publishing a description of it as "the new, ultimate authority" (COD 1998: dustcover). No dictionary is an ultimate authority on a living language, but $C O D$ is rich in Canadianisms and in Canadian encyclopedic information, and its coverage of contemporary world English is generally very good. In my opinion, it is at present the best general dictionary of Canadian English.

COD was reissued with a supplement of new words in 2001, and released on CD-ROM in 2002. It has generated several offshoots: The Canadian Oxford Spelling Dictionary in 1999; The Canadian Oxford Paperback Dictionary (this title suggests misleadingly that this abridged dictionary is the full COD in soft covers) in 2000; The Canadian Oxford High School Dictionary in 2001; The Canadian Oxford Compact Dictionary in 2002. A couple of these challenge Gage and other companies in the children's market: My Very First Canadian Oxford Dictionary, with illustrations, appeared in 2002, and My First Canadian Oxford Dictionary, also with illustrations, in 2003 (apparently my very first means "my first" in these titles and my first means "my second").

\section{Lexicography in Canada in the new millennium}

Some of the most dynamic lexicographical work being done in Canada as the new millennium begins is concerned with languages other than English. The Alberta Elders' Cree Dictionary, for instance, has made a striking partnership between academic lexicography and community ownership of a language: published by the University of Alberta Press, under the general editorship of a professor at that university, Earle Waugh, it has nevertheless, as the title suggests, been shaped by native speakers of Cree. It is described in its preface as "a gift from the elders to the Cree people of Alberta", and its principal maker, 
George Cardinal, calls it "an honoring gift to all my great Cree ancestors" (LeClaire and Cardinal 1998: xiii, xi). A similar sense of heritage pervades a dictionary of the distinctive variety of Low German spoken in western Canada by the ethno-religious group called Mennonites, Jack Thiessen's MennonitischPlautdeutsches Wörterbuch/Mennonite Low German Dictionary, "a labour of love" which, in the spirit of DNE and the projects associated with it, and of DPEIE and the Dictionary of Prince Edward Island Sayings, brings a great deal of folkloric and encyclopedic material into its wordlist, "to embody a time and a culture, and a way of life that is rapidly disappearing" (Thiessen 1999: 24; cf. Considine, forthcoming). Other important dictionaries of languages other than English have recently been completed, for instance a Canadian Dictionary of American Sign Language (Bailey and Dolby 2002), which lists 8700 signs within the lexicon of ASL, many of which are distinctive to Canada or even to particular regions within Canada. The dictionary even records a special sign for the most famous hockey player in recent history, Wayne Gretzky (National Post 10 July 2002: A1). Others are still in progress, such as the Dictionary of Old English being undertaken at the University of Toronto, whose editors had by the end of 2002 begun drafting entries for words beginning with the letter I (Holland 2003). One important dictionary of a non-Canadian variety of English which is at present in progress is that of Lise Winer of McGill University, Montréal, who has since 1980 been at work on a dictionary of the English of Trinidad (Haldane 2003).

The lexicography of modern English in Canada has changed dramatically in the last fifty years. There are still some Canadians who believe that there is no distinctive national standard for formal written English in Canada: "all Canadian dictionaries are rather useless", wrote one in an online posting; "[a]ny Canadian usages you use you obviously already know, and there is no tyranny of proper usage when it comes to the ones you don't" (Anon c2003). But generations of lexicographical work, from the pioneering Winston Simplified Dictionary for Canada in 1937 through the Gage dictionaries of the 1960s to their offspring and the numerous competitors of those offspring, have changed educated opinion. So, for instance, the $\mathrm{CBC}$, which had been content to appeal to "an Oxford and a Webster's dictionary" in 1949, responded to a criticism in 2001 (it had transcribed the gig is up, meaning roughly "the party's over" as the jig is up, meaning roughly "the scheme's been foiled, the game's up" in an online posting) by citing the Canadian Oxford Dictionary, a Webster's dictionary, the Oxford English Dictionary, the Gage Canadian Dictionary, and the Houghton Mifflin Canadian Dictionary (Shewchuk 2001).

One aspect of the future of English-language lexicography in Canada is predictable: the lucrative school and university market will continue to be tapped. This may not be a matter of making highly original dictionaries: at the time of writing, the educational publisher Harcourt Canada is completing a new edition of the Winston Canadian Dictionary, which will be based on Thomas Paikeday's Winston Dictionary of Canadian English, Intermediate Edition of 1969, 
which was itself, as we have seen, based on an American dictionary of 1966 (Kretchman 2003). The revision has been entrusted to a couple who trade as "Focus Strategic Communications Incorporated: Packagers for Publishers", rather than to full-time lexicographers or academics (Focus Strategic Communications 2003). Their work is unlikely to produce results superior to those achieved in twenty-five person-years by the makers of $C O D$. More elaborate projects may subsume Canadian English within general American English, as does the Microsoft Encarta College Dictionary, which has consultants for some major varieties of English spoken outside the US (including Margery Fee of the University of British Columbia for Canada, Rajend Mesthrie for South Africa, and Eva Hertel of the Chemnitz University of Technology for East Africa), and has four Canadians, including Terry Pratt, on its College Usage Advisory Board. The lexicography of Canadian English is too important for it to be handed over to "packagers for publishers" or to publishers for the general American market. The only way for it to move forward will be to take the route pioneered by Paikeday and subsequently taken by COD: the best dictionaries of Canadian English will make increasing use of carefully constructed databases rich in Canadian and worldwide material in English, and they will be made by the full-time staff of publishers' dedicated dictionary departments, conceivably in partnership with universities or the federal government.

The academic lexicography of Canadian English is clearly capable of being developed in two respects. The first is the making of regional dictionaries like $D N E$ and DPEIE, and at a similar scholarly level to these two. Such dictionaries could in theory be compiled for each of the maritime provinces, namely Nova Scotia and New Brunswick, for the three prairie provinces as a single unit of inquiry, for the far north of Canada, and for British Columbia. The second is, in effect, the finishing of the great unfinished Canadian dictionary: the Dictionary of Canadian English on Historical Principles. The Dictionary of Canadianisms was never intended to be, as it has de facto become, the sole historical record of Canadian English, and the Australian National Dictionary and the Dictionary of South African English on Historical Principles show that the age of the making of major historical dictionaries is not yet past. There is an important respect in which Canada is, at the beginning of the twenty-first century, lagging behind Australia and South Africa in the documentation of its own variety of English, just as it was at the beginning of the twentieth.

\section{References}

Anon "from Vancouver, Canajah" [online]. c2003. Available: <http://www.amazon.ca>, listing for Funk \& Wagnalls Canadian School Dictionary [viewed May 23, 2003].

Avis, Walter S. and A.M. Kinloch. 1978. Writings on Canadian English 1792-1975: An Annotated Bibliography. Toronto: Fitzhenry and Whiteside.

Bailey, Carol Sue and Kathy Dolby (Eds.). 2002. Canadian Dictionary of American Sign Language. Edmonton: University of Alberta Press. 
Bassler, Gerhard P. 1991. The German Canadian Mosaic Today and Yesterday. Ottawa: German-Canadian Congress.

Bélisle, Louis-Alexandre. 1954-57. Dictionnaire général de la langue française au Canada. Québec: Bélisle.

A Brief Glossary of Canadian Expressions Collected by An Enquiring Englishman. 1889/1980-. St. John's Church Parish Notes: 39-40. St. John, NB: J. and A. McMillan for St. John's Church. CIHM/ICMH Microfiche Series fiche 93580. Ottawa: Canadian Institute for Historical Microreproductions.

British Columbia Archival Union List [online]. 2003. Available: <http://mayne.aabc.bc.ca> [viewed May 28, 2003].

Canadian Dictionary/Dictionnaire canadien. 1962. Vinay, Jean-Paul, Pierre Daviault, and Henry Alexander (Eds.). Toronto: McClelland and Stewart.

Canadian Dictionary of Abbreviations. 1994. Dobroslavic, Thérèse and Gail Edwards (Eds.). Previous edition published as Abbreviations: A Canadian Handbook. Toronto: ECW Press.

Canadian Dictionary of Safety Terms. 1987. Ottawa: LARR Enterprises and RAM Consulting.

Canadian International Trade Tribunal. 1989. Appeal 3003: Bowne of Canada, Inc., v. the Minister of National Revenue [online]. Available: <http://www.citt-tcce.gc.ca/appeals/decision/ apin89_e.asp\#89> [viewed May 28, 2003].

Cartier, Jacques. 1534/1986. Relations. Michel Bideaux (Ed.). Bibliothèque du Nouveau Monde. Montréal: Presses de l'Université de Montréal.

Cartwright, George. 1792. A Journal of Transactions and Events, During a Residence of Nearly Sixteen Years on the Coast of Labrador; Containing Many Interesting Particulars, Both of the Country and its Inhabitants, Not Hitherto Known. 3 vols. Newark, UK: Allid and Ridge.

Chambers, J.K. 1993. 'Lawless and Vulgar Innovation': Victorian Views of Canadian English. Clarke, Sandra (Ed.). 1993. Focus on Canada: 1-26. Amsterdam/Philadelphia: John Benjamins.

Clapin, Sylva. 1913. Ne pas dire, mais dire: inventaire de nos fautes les plus usuelles contre le bon langage. Worcester, Mass.: J.A. Jacques.

Clapin, Sylva (Ed.). 1894. Dictionnaire canadien-français ou lexique-glossaire des mots, expressions et locutions ne se trouvant pas dans les dictionnaires courants et dont l'usage appartient surtout aux Canadiens-français. Montréal: C. O. Beauchemin et fils.

Clapin, Sylva (Ed.). 1902. A New Dictionary of Americanisms, Being a Glossary of Words Supposed to be Peculiar to the United States and the Dominion of Canada. New York: L. Weiss.

Clapin, Sylva (Ed.). 1905. Nugent's Up-To-Date English-French and French-English Dictionary According to the Best Authorities, and Containing All the Words Generally Used in Both Languages/ Nugent - Nouveau dictionnaire Français-Anglais et Anglais-Français rédigé d'après les meilleures autorités, et contenant tous les mots généralement en usage dans les deux langues. Montréal: Librairie Beauchemin.

COD (Canadian Oxford Dictionary). 1998. Barber, Katherine (Ed.). Toronto: Oxford University Press.

Concise Dictionary of Canadianisms. 1973. Abridgement of DC. Toronto: Gage Educational Publishing.

Considine, John. 2000. Fourteen Words for Moose: Cultural and Intercultural Contexts of Four Canadian Dictionaries, 1977-1998. Antor, H. and K. Stierstorfer (Eds.). 2000. English Literatures in International Contexts: 317-331. Anglistische Forschungen 283. Heidelberg: Carl Winter Universitätsverlag. 
Considine, John. Forthcoming. Dialectology, Storytelling, and Memory: Jack Thiessen's Mennonite Dictionaries. Antor, H., S.M. Brown, J.P. Considine, and K. Stierstorfer (Eds.). Refractions of Germany in Canadian Literature and Culture. Berlin/New York: De Gruyter.

Crystal, David. 1995. Cambridge Encyclopedia of the English Language. Cambridge: Cambridge University Press.

Crystal, David. 1998. Language Play. Harmondsworth, UK: Penguin.

DC (A Dictionary of Canadianisms on Historical Principles). 1967. Avis, Walter S. (Ed.). Charles Crate, Patrick Drysdale, Douglas Leechman, and Matthew H. Scargill (Ed. board). Charles J. Lovell (Ed. until 1960). Toronto: W.J. Gage.

De Wolf, Gaelan Dodds. 1992. Social and Regional Factors in Canadian English: A Study of Phonological Variables and Grammatical Items in Ottawa and Vancouver. Toronto: Canadian Scholars' Press.

DNE (Dictionary of Newfoundland English). 1982ํ․ Story, G.M., W.J. Kirwin, and J.D.A. Widdowson (Eds.). Toronto: University of Toronto Press.

DNE (Dictionary of Newfoundland English). 1989². Story, G.M., W.J. Kirwin, and J.D.A. Widdowson (Eds.). Toronto: University of Toronto Press.

DNE (Dictionary of Newfoundland English) [online]. 19992. Story, G.M., W.J. Kirwin, and J.D.A. Widdowson (Eds.). Available: <http://www.heritage.nf.ca/dictionary/> [viewed May 30, 2003].

DPEIE (Dictionary of Prince Edward Island English). 1988. Pratt, T.K. (Ed.). Toronto: University of Toronto Press.

Dulong, Gaston. 1966. Bibliographie linguistique du Canada français. Québec: Les Presses de l'Université Laval/Paris: Librairie C. Klincksieck.

Dzwonkoski, David. 1986. Holt, Rinehart and Winston. Dzwonkoski, Peter (Ed.). 1986. American Literary Publishing Houses, 1900-1980: Trade and Paperback: 190-91. Dictionary of Literary Biography 46. Detroit: Gale Research.

Everhart, Jim. 1968. The Illustrated Texas Dictionary of the English Language. Houston: Creative Books. Federal Court Reports. 1994. Canada v. Seaboard Lumber Sales Co. [online]. Available: <http:// reports.fja.gc.ca/fc/1994/pub/v3/1994fca0256.html> [viewed May 28, 2003].

Focus Strategic Communications [online]. 2003. Available: <http://www.focussc.com/packpub. html> [viewed May 29, 2003].

Funk and Wagnalls Standard College Dictionary: Canadian Edition. 19631. Toronto: Longmans Canada.

Funk and Wagnalls Standard College Dictionary: Canadian Edition. 19732. Toronto: Fitzhenry and Whiteside.

Gage Canadian Dictionary. 19966. De Wolf, Gaelan Dodds (Ed.). Toronto: Gage Educational Publishing.

Gage Canadian Dictionary. 20007. De Wolf, Gaelan Dodds (Ed.). Vancouver/Toronto: Gage Educational Publishing.

Gage Learning [online]. 2003. Available: <http://www.gagelearning.com> [viewed May 28, 2003].

Geikie, A. Constable. 1857/1980-. Canadian English. Canadian Journal of Science, Literature, and History 2(11): 344-55. CIHM/ICMH Microfiche Series fiche P05122-077308. Ottawa: Canadian Institute for Historical Microreproductions.

Goddard, Ives. 1996. The Description of the Native Languages of North America before Boas. Goddard, Ives (Ed.). 1996. Handbook of North American Indians vol. 17: Languages: 17-42. Washington, DC: Smithsonian Institution. 
Gregg, R. J. 1962. Canadian Lexicography [review of The Canadian Dictionary/Dictionnaire canadien] Canadian Literature 14: 68-71.

Haldane, Maeve. 2003. Compiling Creole in the Caribbean. McGill Reporter 35(16) [online]. Available: <http://www.mcgill.ca/reporter/16/winer/> [viewed May 29, 2003].

Halford, Peter W. (Ed.). 1994. Le français des Canadiens à la veille de la Conquête: Témoignage du père Pierre Philippe Potier, s.j.. Collection Amérique Française 2. Ottawa: University of Ottawa Press.

Hansard [Nova Scotia]. 2001. Debate in the fifty-eighth general assembly of the Legislature of Nova Scotia, May 11 [online]. Available: <http://www.gov.ns.ca/legislature/hansard/han58-2/ h01may11.htm $>$ [viewed May 28, 2003].

Hewson, John. 1978. Beothuk Vocabularies: A Comparative Study. Technical Papers of the Newfoundland Museum 2. St John's: Newfoundland Museum.

Holland, Joan. 2003. Dictionary of Old English: 2002 Progress Report [online]. Available: <http:// www.doe.utoronto.ca/Progress2002-web.pdf $>$ [viewed June 3, 2003].

Houghton Mifflin Canadian Dictionary of the English Language. 1980. Morris, William (Ed.). Markham, ON: Houghton Mifflin Canada.

ITP Nelson Canadian Dictionary of the English Language. 1997. Scarborough, ON: ITP Nelson.

Kirwin, W.J. 1975. Selecting and Presenting the Lexicon. Regional Language Studies 6: 5-9.

Kirwin, W.J. and G.M. Story. 1986. The Etymology of High Liner: Problems of Inclusion in the Dictionary of Newfoundland English. American Speech 61(3): 281-284.

Kister, Kenneth F. 1977. Dictionary Buying Guide: A Consumer Guide to General English-language Wordbooks in Print. New York: R.R. Bowker.

Kretchman, Julie (Editorial Director, Harcourt Canada). 2003. Personal communication, May 28.

Landau, Sidney I. 1984/1989. Dictionaries: The Art and Craft of Lexicography. New York: Charles Scribner's Sons. Reprinted Cambridge: Cambridge University Press.

Lauder, Afferbeck [i.e. Alistair Morrison]. 1965. Let Stalk Strine. Sydney: Ure Smith.

LeClaire, Nancy and George Cardinal. Alberta Elders' Cree Dictionary/alperta ohci kehtehayak nehiyaw otwestamâkewasinahikan. Waugh, Earle (Ed.). Edmonton: University of Alberta Press/Duval House.

Lovell, Charles J. 1955a. Lexicographic Challenges of Canadian English. Journal of the Canadian Linguistic Association 1(1): 2-5.

Lovell, Charles J. 1955b. Whys and Hows of Collecting for the Dictionary of Canadian English I: Scope and Source Material. Journal of the Canadian Linguistic Association 1(2): 3-8.

Lovell, Charles J. 1956. Whys and Hows of Collecting for the Dictionary of Canadian English II: Excerption of Quotations. Journal of the Canadian Linguistic Association 2(1): 23-32.

Malong, Rawbone [i.e. Robin Malan]. 1972. Ah Big Yaws? A Guard to Sow Theffricun Innglissh. Cape Town: David Philip.

McConnell, Ruth E. 1978. Our Own Voice: Canadian English and How it Came to Be. Toronto: W.J. Gage.

Memorial University. 2003. English Language Research Centre [online]. Available: <http://www. mun.ca/english/elrc.html> [viewed June 3, 2003].

Microsoft Encarta College Dictionary. 2001. New York: St Martin's Press.

Moreton, Julian. 1863. Life and Work in Newfoundland: Reminiscences of Thirteen Years Spent There. London: Rivingtons. 
National Library of Canada. 2003. Amicus Web [online]. Available: <http://www.nlc-bnc.ca> [viewed May 28, 2003].

Orkin, Mark M. 19731. Canajan, Eh? Don Mills, ON: General Publishing.

Orkin, Mark M. 1997³. Canajan, Eh? Toronto: Stoddart.

Oxford University Press. 1997. The Canadian Oxford Dictionary: The Foremost Authority on Current Canadian English [advertising brochure]. Toronto: Oxford University Press.

Paikeday, Thomas M. 1989. Revolutionizing Dictionaries [review of Morton Benson, Evelyn Benson, and Robert Ilson, The BBI Combinatory Dictionary of English: A Guide to Word Combinations]. American Speech 64(4): 354-362.

Paikeday, Thomas M. 1992. O Corpora! Lexicographica 8: 307-317.

Penguin Canadian Dictionary. 1990. Paikeday, Thomas M. (Ed.). Markham, ON: Penguin Books.

Parkin, Tom. 1989. WetCoast Words: A Dictionary of British Columbia Words and Phrases. Victoria, BC: Orca.

Poteet, Lewis J. 1983. The South Shore Phrase Book. Hantsport, NS: Lancelot Press.

Pratt, Terry and Scott Burke (Eds.). 1998. Prince Edward Island Sayings. Toronto: University of Toronto Press.

Pratt, Terry. 1999. Personal communication, September 27.

Rudnyckj, J.B. 1962-1. An Etymological Dictionary of the Ukrainian Language. 22 fascicles. Winnipeg: Ukrainian Free Academy of Sciences.

Rudnyckj, J.B. 1966-2. An Etymological Dictionary of the Ukrainian Language. 10 fascicles. Winnipeg: Ukrainian Free Academy of Sciences.

Sandilands, John. 19121/1976-. Western Canadian Dictionary and Phrase-book: Explaining in Plain English for the Special Benefit of Newcomers the Meaning of the Most Common Canadianisms and Colloquialisms. Winnipeg: printed for the editor. Peel Bibliography on Microfiche fiche 2342. Ottawa: National Library of Canada.

Sandilands, John. 19132/1975. Western Canadian Dictionary and Phrase-book: Things a Newcomer Wants to Know. Winnipeg: printed for the editor. John Orrell (Ed.). Facsimile reprint. Edmonton: University of Alberta Press.

Scargill, M.H. 1958. Canadian Dictionary Projects II: Canadian English. Journal des traducteurs 3(3): 114-121.

Scargill, M.H. 1967. Preface. Avis, Walter S. (Ed.). 1967. A Dictionary of Canadianisms on Historical Principles: vi-vii. Toronto: W.J. Gage.

Seary, E.R. 1971. Place Names of the Avalon Peninsula of the Island of Newfoundland. Toronto: University of Toronto Press for Memorial University of Newfoundland.

Seary, E.R. 1977. Family Names of the Island of Newfoundland. With Sheila M. P. Lynch. St John's: Memorial University of Newfoundland.

Shewchuk, Blair. 2001. Gigs, Jigs, and Jibes [online]. Available: <http://www.cbc.ca/news/ indepth/words/gigijg.html> [viewed May 27, 2003].

Société du parler français au Canada. 1930. Glossaire du parler français au Canada. Québec: L'Action Sociale.

Story, G.M. 1956. A Newfoundland Dialect Dictionary: A Survey of the Problems. St John's: Memorial University of Newfoundland.

Story, G.M. 1957. Research in the Language and Place-Names of Newfoundland. Journal of the Canadian Linguistic Association 3(2): 47-55. 
Story, G.M. 1975a. A Critical History of Dialect Collecting in Newfoundland. Regional Language Studies 6: 1-4.

Story, G.M. 1975b. Edgar Ronald Seary. Macdonald, A.A., P.A. O'Flaherty, and G.M. Story (Eds.). 1975. A Festschrift for Edgar Ronald Seary: 1-8. St John's: Memorial University of Newfoundland.

Story, G.M. 1989. Review of DPEIE. Canadian Historical Review 70(3): 391-393.

Story, G.M. and W.J. Kirwin. 1974. 'The Dictionary of Newfoundland English': Progress and Promise. Regional Language Studies 5: 15-17.

Story, G.M., W.J. Kirwin and J.D.A. Widdowson. 1973. Collecting for the Dictionary of Newfoundland English. McDavid Jr., Raven I. and Audrey R. Duckert (Eds.). 1973. Lexicography in English. Annals of the New York Academy of Sciences 211: 104-108. New York: New York Academy of Sciences.

Tebbel, John W. 1972-81. A History of Book Publishing in the United States. 4 vols. New York: R.R. Bowker.

Thiessen, Jack. 1999. Mennonitisch-Plautdeutsches Wörterbuch/Mennonite Low German Dictionary. Steinbach, MB: Hanover Steinbach Historical Society.

University of Ottawa. 2003. Projet de lexicographie comparée du français et de l'anglais au Canada/Comparative Lexicography Project of French and English in Canada [online]. Available: <http://www.dico.uottawa.ca/> [viewed June 3, 2003].

Vinay, Jean-Paul and Pierre Daviault. 1958. Dictionnaires canadiens I: les dictionnaires bilingues. Journal des traducteurs 3(3): 109-113.

Wees, W.R. 1967. Foreword. Avis, Walter S. (Ed.). 1967. A Dictionary of Canadianisms on Historical Principles: v. Toronto: W.J. Gage.

Winston Canadian Dictionary for School, Home, and Office. 1974. Toronto/Montréal: Holt, Rinehart and Winston of Canada.

Winston Dictionary of Canadian English: Elementary Edition. 1975. Paikeday, Thomas M. (Ed.). Toronto: Holt, Rinehart and Winston of Canada.

Winston Dictionary of Canadian English: Intermediate Edition. 1969. Paikeday, Thomas M. (Ed.). Toronto: Holt, Rinehart and Winston of Canada.

Winston Simplified Dictionary for Canada. 1937. Brown, Thomas Kite and Henry Alexander (Eds.). Toronto: Winston.

The Winston Simplified Dictionary: Including All the Words in Common Use Defined so that they can be Easily Understood. 1919. Lewis, William D. and Edgar A. Singer (Eds.). Philadelphia: John C. Winston. 